\title{
CONCEPTUAL INTERVIEW: PECULIARITIES OF THE GENRE AND THE JOURNALIST'S WORK METHODS
}

\author{
Tetiana Matskevich ${ }^{7}$
}

\begin{abstract}
Peculiarities of conceptual interview as a genre of universal publicism, the journalist's work methods and conditions that enable a complete realization of the genre are analyzed in the article.
\end{abstract}

Key words: conceptual interview, universal publicism, informational journalism, penetrative thought, designing of the outlook.

"Objectivism is a question of a writer's conscience", - as a Polish reporter Ryszard Kapuściński [2001] once said. In fact, this concept is a very ephemeral one; moreover, it is unreal in the context of actual reality. In any case, an author is a co-creator of reality: he interprets it, coloring it with his own attitude, and sends a brand new code into the information matrix. Impartial information is not able to influence the recipients' minds productively, as well as to saturate them with new ideas or provide impetus for positive changes realization. Opinion-making, religious and philosophical thought cutting, crystallization of deeper meanings, the ideals consolidation and the search for truth are the realm of universal publicism, but not of a faceless informational journalism. It is universal publicism that looks for a "thoughtful, competent reader, with an ambitious thesaurus and broad intellectual horizons, who is ready for a dialogue on an equal footing" [Tytarenko, 2011, p. 86].

The balance is substantially upset today: the event facts amount is considerably larger than the area of a high-quality journalism realization. That is why it is important to transform the entire field of journalism, refusing to focus on a readable micro text and passive recipients. Conceptual interview is a universal genre of universal publicism: with its penetration into the collocutor's soul, new ideas production and expansion of the audience outlook horizons, conceptual interview considerably surpasses capabilities of informational (often primitive) interview, based on banal questions.

Interview is rightly considered as one of the most popular genres of journalism. Providing of accurate comments makes it impossible to manipulate with words and protects authors from claims on misinterpretation of others' opinions. In addition, interview enables a multifaceted disclosure of the collocutor's personality by stimulating him or her to reflection and meditation. 
Cognition, imagery, the penetrative thought's depth into reality, ideological content, essential designing of recipients' outlook are main features of conceptual interview. This genre is quite beyond the elementary reportorial activity.

Before a detailed analysis of conceptual interview specifics, we shall explain a key term, which distinguishes this kind in the system the genre typology. Thus, the concept is: 1. A system of views on a certain phenomenon; a way of understanding and interpretation of certain phenomena, the basic idea of any theory. 2. In art it is an ideological and creative vision of a work. Accordingly, conceptual is 1. One concerning the concept or containing it. 2. figur. Sage which gives rise to the idea.

Universal publicism makes a considerable contribution to the realm of journalism: it is able to fill every genre, favorable for opinion-making, with unique features. When talking on conceptual interview, any categoricity loses its meaning. A journalist is not focused any more on getting answers to questions: "What? Where? When? (informational genre) or Why? How? What does it mean? (analytical one, focused on the analysis of the fact)" [Tertychnyi, 2000]. Multidimensionality of the concept (in the sense of a meaning of a mark (name)) expands horizons automatically, transforming the whole system of coordinates. A conversation is transformed from a usual mean of information gathering into constructive dialogue between two equal individuals, one of which directs the conversation back on track as necessary, coordinates the process and, most importantly, is able to understand his collocutor; the second one, by contrast, not only involves into the essence of the phenomenon or process, but interprets its causes and consequences not banally, provides a productive vision of the future in the light of an adequate explanation of the past, even more, goes beyond the causal view on reality, appealing to the eternal truths.

A researcher Christine Davydchak, when analyzing one of the most famous examples of conceptual interview, the interview between Vittorio Messori and Pope John Paul II, published as the book entitled "Crossing The Threshold Of Hope", indicates:

Interview is one of the most interesting genres of journalism, while «conceptual interview is a brilliant example of command of such genre's means as originality, depth and significance of judgments, competency, an inexhaustible intelligence, whereby the function of journalism as an expression of public opinion and the community intellect representative is fully realized. A dialogue interview (a dialogue as a method of searching for truth) has its own role. It is a conversation "on equal footing", initiated by the interviewer, for which a journalist should not just be ready, but also should have an appropriate authority [Davydchak, 2009, p. 74].

Let's consider this example more in detail on the background of the interviewer's work methodology. When it comes to conceptual interview, specifically to the precedent of the conversation between V. Messori and John Paul II, we mean not just a conversation between two interested persons. Moreover, standard methods of training turn out to be not enough. First, a so-called equality of the subjects, on which theorists like to focus (although in practice this equality is far from the ideal one and is rarely based 
on a common "weight class" of the interlocutors) was caused not by a parity status in the society, but only by mutual respect and the ability to understand each other. If the person who responses, and therefore knows much more about the subject-matter of the conversation than the interviewer that asks, treats his interlocutor with respect (not with ironic condescension with a shadow sarcasm!) and tries to explain the problem issue comprehensively, in a way as hundreds of interested persons are sitting in front of him; the interviewer, respectively, is skillful enough to steer the conversation in a constructive direction and to formulate really smart, relevant questions, and is educated so that he is able to understand the interviewee answers, in this case we can rightly speak of equality. It was achieved between V. Messori the Pope, as John Paul II in his responses "showed gratitude and filial sincerity" [John Paul II, 2005, p. 9], moreover, "the fact of such a serious attitude to the humble journalist appears to be another argument, if demanded, of the Pope's obedience, of his generous willingness to listen to the voices of average "Christians from the street" [Ibid., p. 12].

Taking into account the importance of the Pope's person, who is rightly considered the Vicar of Christ on the Earth, it is clear that the interview was not the initiative of the journalist. V. Messori has been chosen among others on the grounds that he writes books and articles on religious subjects, "writing with a secular human liberty, and from a solidary position of the Christian, who is conscious that the Church has been entrusted not only to the clergy, but also all the baptized" [Ibid., p. 8]. First, a television interview had been preparing. Interestingly, that V. Messori had no experience on TV, so, despite his deep religious believes, this condition became a problem for the journalists. In addition, the interviewer thought about whether it was appropriate that the Pope would come to the studio, sit across the table and begin to answer the questions from the normal "in my opinion", in contrast to the solemn "We" in which "the voice of a thousand-year mystery of the Church sounded" [Ibid., p. 11]. Would so the Pontiff undertake a certain risk, because "his voice would be drowned out by the noise of the chaotic world, which was being converted to a banal spectacle, full of conflicting opinions and relentless chatter on each topic?" [Ibid., p. 10-11]. Finally, it was nowhere to retreat, and V. Messori began to think over the questions carefully. He met with John Paul II at Castel Gandolfo before the conversation.

Despite the seriousness of the Pope's intentions, the television interview did not take place because of plenty cases assigned to the Pontiff. However, the head of the Catholic Church did not leave aside the question of the journalist by sending a letter to V. Messori with a promise to answer them, "Because you have put a lot of work to formulate the question, you probably have a right to the answers...I am preparing them and will transfer them to you. Then I ask you use them at your discretion" [Ibid., p. 12]. It A freedom of action, which the Pope gave to the interviewer, is amazing. Even more, the understanding with which that he treated the journalistic work, namely the burdensome routine such as formulating of questions, is amazing as well! Obviously, in this case, the person's position does not play a sufficient role. Respect for the labor of others is caused only by the person's own humanity that is one of the most important features of the individual, but is peculiar to not all humans. 
When a person has something to say and wants to share his or her views, he or she will be able to make it even in front of a person, who is smart not enough. It is important that the interviewee feels that the journalist is worth trusting; he shall see hundreds of other eyes that need explanation in him. When answering the journalist's questions, the Pope spoke as if millions of people in the world were listening to him; some doubts of the interlocutor, his vulnerability as a human, and, most importantly, a sincere desire to find the truth (without which a real journalism is not possible) facilitated a constructive dialogue. During the interview V. Messori "was plunging into the depths of the issue, familiarizing with the ideological context thoroughly, discovering new names, figures, events, concepts and deciphering controversies" [Davydchak, 2009, p. 74]. This does not mean that the journalist formulated the questions not professionally, and the Pope had to edit them thoroughly and to direct them in the most optimal channel for understanding. On the contrary, the Pontiff treated the interviewer's scheme carefully and answered all 20 (!) questions. He involved in the conversation issues (this fact was facilitated by the written form) so thoroughly and extensively, that V. Messori, having read the Pope's answers, had introduce further questions into the dialogue, in order to make the conversation more logical and elegant. In passing, we note a way of the journalist's work. He immediately rejected "all sorts of "clerical" themes associated with "ecclesiastical bureaucracy" and constitute almost one hundred percent of the information (or misinformation) wrongly named as "religious"'" [John Paul II, 2005, p. 14]. V. Messori tried not to waste time, obtained for an exceptional opportunity to talk with the Pope. Faith is more important than decisions of the church and controversial issues of morality and even more important than the Vatican. "Its undeniable facts and uncertainties; crisis, which allegedly threatened it; the very possibility of faith today in cultures, which treats as provocation and intolerance the statements that there are not only thoughts, but there is the capitalized Truth" [Ibid.]. Since this moment we begin analysis of methods of preparation for the interview.

A scholar Volodymyr Zdoroveha advises to follow approximately the following scheme:

- to select the object and the subject-matter for the conversation;

- $\quad$ to study necessary documents;

- to make contact with the interlocutor;

- $\quad$ to develop the questions. A poor wording results from incompetence, laziness, and ignorance of interlocutor's psychology;

- to try to inspire confidence of the collocutor, to be able to amaze, to engage in the conversation reasonably and to finish it in time [Zdoroveha, 2004, p. 180].

It is a good concept, partially acceptable for designing of conceptual interview as well. However, in the context of universal publicism it is not enough. Let us ass more details using a comparative table by Mariya Tytarenko, in which the researcher compares universal publicism (UP) and informational journalism (IJ):

a creator of UP (and therefore of conceptual interview as its genre) is 
not just a media employee or a reporter, but "a journalist, columnist, commentator, writer, thinker, torch" [Tytarenko, 2006, p. 123];

- $\quad$ the issue is not a readable micro text, focused on mass audience, but a writable macro text, completed with the recipient's views (according to McLuhan)

- $\quad$ purpose of UP is to explain processes, complicated for understanding, to implement constructive ideas, to search for truth, and to try to solve outlook problems of qualitatively;

- an author's mindset is "stereoscopic, specifically-shaped, holistic, cosmic, universal" [Ibid., p. 125];

- personal form of journalism; information is "ecologically clear".

To illustrate the implementation of the requirements listed above, let's mention conceptual interview of Philip Roth with Milan Kundera that was published in 1994 in the Ukrainian language under the title "Comprehend the world as a question" translated by Constantine Vronsky. The subjects of the conversation were not only a journalist and a man who had something to say the audience. The two internationally renowned writers got together, one of which served as the interviewer and yet was so respected person that respect from his equally esteemed collocutor was not even needed to achieve equality. In fact, the conversation took place between the two "heavyweights". Thus, it is not surprising that it became so unexpectedly constructive. The interview was published in the early 80 's as a preface to the English translation of $\mathrm{M}$. Kundera's novel "The Book of Laughter and Forgetting". So many political events, which are mentioned, are no longer up-to-date. But the author's accurate considerations on "totalitarianism, Russian expansion and, of course, an artist's role in the modern world still remain appropriate, even necessary for a modern reader" [Kundera, 1994, p. 134]. However, we do not focus attention on the details of the communication, paying our attention only to the mazes of the conversation and skilled questions of Ph. Roth.

"Do you expect our world to die soon?" [Ibid.] Even he first question of the interviewer puzzles and intrigue a reader who undoubtedly expected something like questioning about a new book by M. Kundera, its deeper meaning, and perhaps references to a certain fact directly related to the writer and would definitely interest the audience. The tone of the conversation is the set and, by the way, sustained to the end without any "wrong" flaws or turns. The interviewee "takes a punch" with dignity and says: "It depends on what do you mean by the term "soon"'" [Ibid.]. Later recipient finds out why Ph. Roth has formulated the question in such way. The feeling that "the world is racing to the death" has arose in M. Kundera's mind long ago, and the anxiety caused by this, has become the theme of all the stories from "The Book of Laughter and Forgetting", even those of a humorous content. We see that the interviewer does not simply formulate appropriate questions and makes the interlocutor "open the card", but also is brilliantly familiar with the subject-matter of the conversation and is able to involve into its essential characteristics, since he is s writer as well.

Further conversation goes beyond giving commentaries to the writer's new book, its subjects branch out covering problems of disappearance of nations ("A man knows that he is mortal, but believes his nation is eternal" [Ibid., p.135]), Eastern and Western Europe ("Post-war takeover of Central Europe (actually, of its main part) by Russian civilization deprived Western Culture of its vital center" [Ibid.]), forced emigration 
(although "the world can be understood only after being seen from several sides" [lbid.]), laugher as the expression of radically different metaphysical reactions: totalitarianism (which is hell and a dream of heaven at the same time): clash of personal and public, sex and sexuality, the existence of the novel as a genre in modern literature. $\mathrm{Ph}$. Roth is familiar with the facts from his collocutor's work, user plot examples and characters created by $\mathrm{M}$. Kundera, while skillfully guiding the interviewee towards deeper involving into reality, self-reflection, and outlining a vision of the future. "Human stupidity lies in the following: they have answers to all questions" [Ibid., p. 137] as M. Kundera said. He destroys an unsteady myth that large, truly profound and erudite personalities can solve global problems by one quirk, one good expression or one honorable act. No, they are actually just "a salt of the earth" and are rarely children of their own time, because they unconsciously answer the questions of the future. Atlases, on whose shoulders the vault of search for eternal truths and desperate overcoming of hopelessness (sometimes fatally rhetorical in its basics) fell. The geniuses in which nation looks for itself. And above all, just people who are, however, able to see more than others.

"Conceptual interview means primarily conceptual questions, a primary author's monologue, which develops into a dialogue with a collocutor" [Davydchak, 2009, p. 75]. It differs from other variations of the genre due to its high intellectual level, constructive dialogue, deep answers, claim to exhaustive conclusions, appealing to fundamentals, thirsty search for the truths lost just like beads by the humanity during its clumsy flight forward; an interviewee's self-reflection, that becomes a precedent and impetus for the recipients' self-analyzes.

Interview can be considered as a truly conceptual, constructive, and deep-forming one, only when relationship between a journalist and an interviewee is established. This contact is based on the questionnaire's talent and honesty and on the speakers' tolerance and openness at the same time. Ch. Davydchak summed up in such a way:

A qualitative conceptual interview is possible only in the case of joint efforts of both sides and depends not only on their intellectual or professional level but on tact, respect and understanding of the status and position of each other as well [Ibid.].

\section{References}

DAVYDCHAK, C. (2009). Christian methology of publicism. Visnyk of the Lviv University (Series Journalism), 35, 73-87.

ZDOROVEHA, V. (2004). Theory and Methods of journalistic work. Lviv: PAIS.

JPHN PAUL II. (2005). Perestupiti porig nadii [Crossing the threshold of hope]. Lviv: Svichado.

KAPUŚCINSSI, R. (2001). Autoportret reportera [Self-Portrait of a Reporter]. Kyiv: Tempora.

KUNDERA, M. (1994). Comprehend the world as a question. Universe, 9, 134-137.

NECHVOLOD, L. (2007). Suchasnij slovnik inshomovnikh sliv [A modern dictionary of foreign words]. Kharkov: Torsing PLUS.

TERTYCHNYI, A. (2000). Zhanry periodicheskoi pechati [Genres of Periodicals]. Retrieved from: http://evartist. narod.ru/text2/01.htm

TYTARENKO, M. (2011). Twofaced Janus: Philosophical and Ideological publicistics. Visnyk of the Lviv University (Series Journalism), 35, 83-100.

TYTARENKO, M. (2006). Universal Publicism: polemic discourse Attempt. Visnyk of the Lviv University (Series Journalism), 28, 118-134. 
And the third category of publications consideres Ukraine to has been historicaly determined as Russian's sphere of influence. Even though there was a great gap between, for instance, Russian and Britain empires ("Russian Empire only exploited its citizens, while Britain supplied them with some goods" [Конквест, 2003, p. 295]), former European empires have the similar postimperialistic outlook, that implies they could sometimes understand Russia's territorial encroachment. "When a commentator claims that Russia feels threatened by the advance of NATO in Eastern Europe or Ukraine's approach to the EU, he's basically implying that Russia does indeed have an inalienable right to claim rights in the region, as if Eastern Europe was nothing but a tool to compensate Russia's unresolved inferiority complexes" [Belafatti, 2014].

\section{New Orienatlism: falling victim to stereotyped thinking}

To crown it all, it is necessary to appeal to one more ideological approach in the system of which all these media misconceptions can be built. The attitude toward Ukraine occasionally resembles the principles of new orientalism.

In 1978, Edward W. Said published his world-known "Orientalism," a book that provided a basis for modern postcolonial studies. He coined the term "new orientalism" to denote a very special approach to the Orient, which imlplies that the western conception of East and "Another" has very little in common with the real face of that part of the World.

The bottom line is, that new orientalism is not about what the real face of the Orient is, but it is about how it is seen "from the height" of West."Being European or American means that you belongs to that part of mankind, which has absolutey definete history of the relations with the Orient", - Said claims [2001, p. 24].

And the essence of this relations is the idea of perpetual ontological difference between East and West. Intricate socipolitical processes in the East are embedded in a simplified scheme. "Western commentators consistently looked (and look) at the Orient as an entity incapable of evolving, stuck in an endless past of decadence and backwardness" [Belafatti, 2014]. Therefore, goes on Said, "the possibility of development, transformation and progress ... are not consistent with the notion of Orient and oriental" [Саїд, 2001, p. 271]. Nowadays, latent orientalism is exceedingly close to racism.

Thus, the Orient is normally associated with rebels, terrorists, debilitated power, sociopolitical restlessness, volatility and instability. European mentalsuzeranity admits the backwardness and the remoteness of the Orient. It is something which is successfully explored at a distance, but nobody wants to go deep.

Likewise, western journalists are also perfunctory about the Ukrainian crisis. The new orientalism has set a template, and XXI centuary journalism followed. Ukrainian internatioanal image is stereotyped. The Russian impact on Ukrain is being overestimated. And any national movements are seen by pro-russian commentators as "fascist".

It was Kwame Nkrumah to assert, while speaking about the neo-colonial subtext 